Animal Health Research Institute,

Damanhour Branch

\title{
BACTERIOLOGICAL STUDY ON SOME CANNED FISH IN BOHAIRA PROVINCE
}

(With 6 Tables)

By

OMAIMA A. SALEH; SEHAM GORGY and A.A. BKHEIT (Received at 18/12/2006)

دراسة بكتريولوجية على بعض الأسماك المعلبة بمحافظة البحيرة امبيه عبل الفتاح صالح ، سهام فؤاد جورجى ، احد ابو المجد بخيت

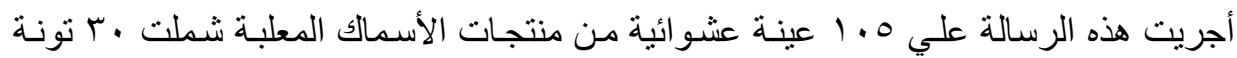

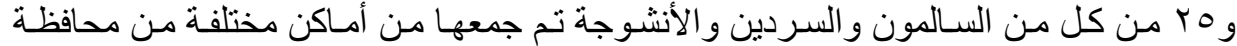

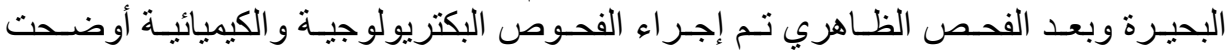

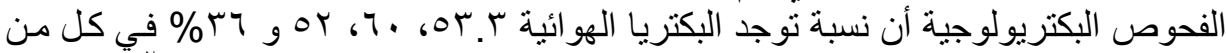

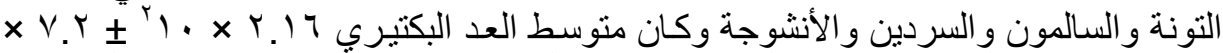

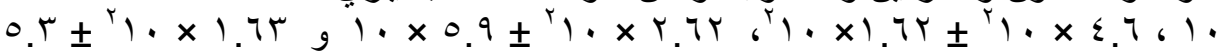

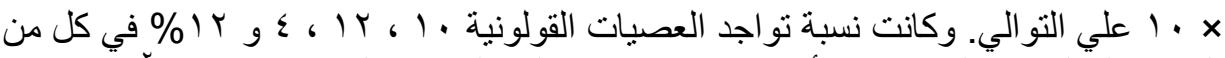

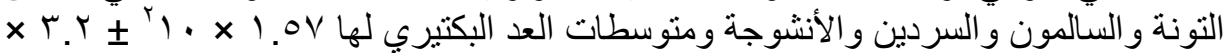

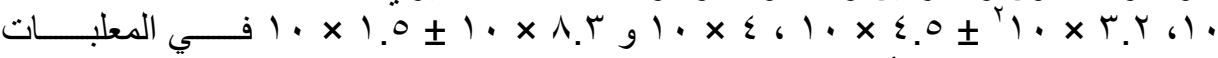

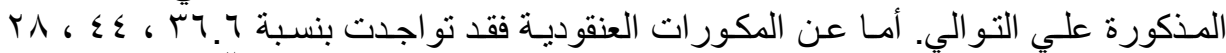

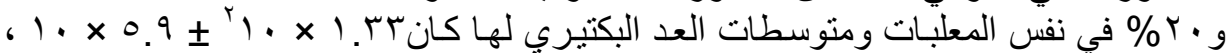

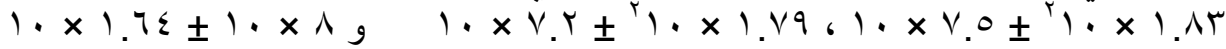

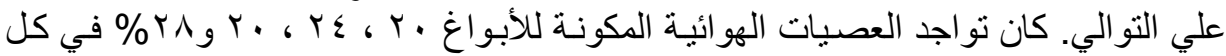

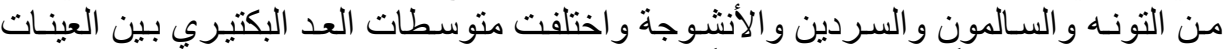

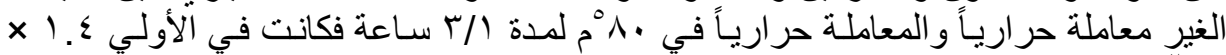

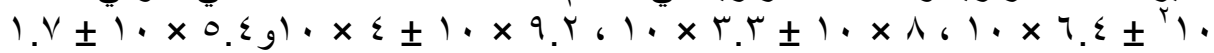

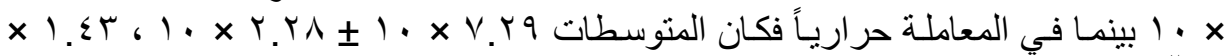
.

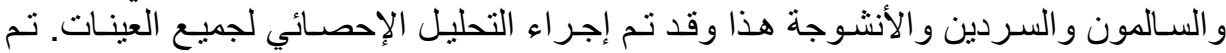

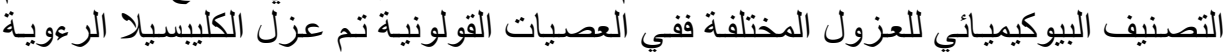

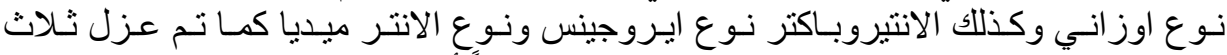

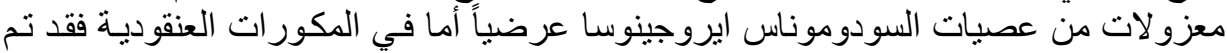

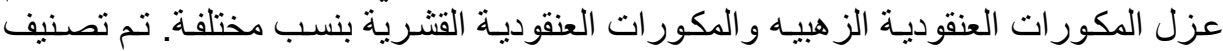

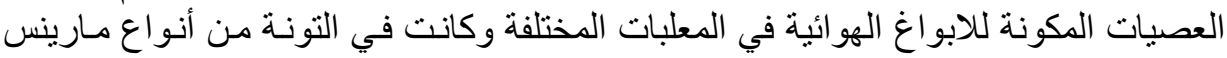

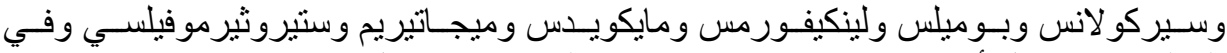

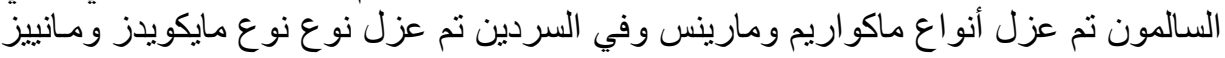




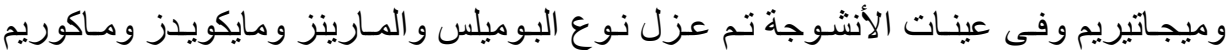

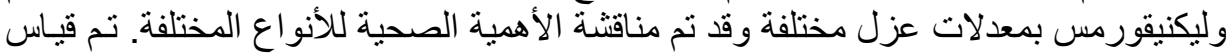

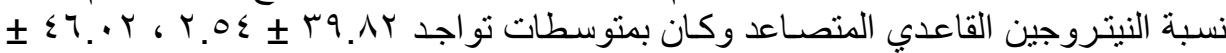

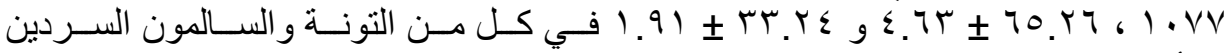

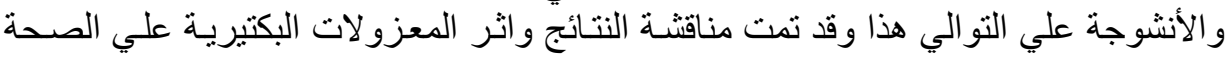

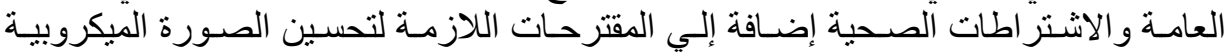
و الكيميائية لتلاك المنتجات السمكية المعلبة.

\section{SUMMARY}

105 random sample of canned fishes included (30 tuna, 25 of each salmon, sardine and anchovies) were collected from different localities and retailed shops in Al-Bohaira province. Samples were submitted for bacteriological and chemical examinations. The aerobic bacteria were detected in 53.3, 60, 52 and $36 \%$ of tuna, salmon, sardine and anchovies respectively with mean values of $2.16 \times 10^{2} \pm 7.2 \times 10,4.6 \times 10^{2} \pm 1.62$ x $10,2.62 \times 10^{2} \pm 5.9 \times 10$ and $1.63 \times 10^{2} \pm 5.3 \times 10 / \mathrm{g}$, respectively of same products. Coliformes could be detected in 10, 12, 4 and $12 \%$ with mean values of $1.57 \times 10^{2} \pm 3.2 \times 10,3.2 \times 10^{2} \pm 4.5 \times 10,4 \times 10,8.3 \times$ $10 \pm 1.5 \times 10$ for tuna, salmon, sardine and anchovies respectively. The mean counts for staphylococci were $1.33 \times 10^{2} \pm 5.9 \times 10,1.83 \times 10^{2} \pm$ $7.5 \times 10,1.79 \times 10^{2} \pm 7.2 \times 10,8 \times 10 \pm 1.6 \times 10$ respectively. The biochemical identification of the gained isolates revealed only 10 isolates of coliforms in all samples $(9.5 \%)$ included Klebsiella pneumoniae sub ozaenae, Enterobaeter aerogens and Enterobacter intermedium in incidences 3.8, 4.8 and $0.1 \%$ respectively. Three isolates of Psudomonals aeruginosa were detected in tuna. Staphylococci were detected in 36.6, 44, 28 and $20 \%$ in tuna, salmon, sardine and anchovies. Staphylococcus aureus and Staphylococcus epedermidis were detected with variable incidence. Bacillus spp. were detected in heat treated samples and non heat treated in variable incidences. Its mean counts varied from crude unheated treated samples and those heat treated at $80 \mathrm{c}$ for $1 / 3$ hour. In the first it were $1.4 \times 10^{2} \pm$ $6.4 \times 10,8 \times 10 \pm 3.3 \times 109.2 \times 10 \pm 4 \times 10$ and $5.4 \times 10 \pm 1.7 \times 10$ while in heat treated it were $7.29 \times 10 \pm 2.28 \times 10,1.43 \times 10^{2} \pm 5 \times 10$, $9.2 \times 10 \pm 3.3 \times 10$ and $5.57 \times 10 \pm 0.99 \times 10$, in tuna salmon sardine and anchovies respectively The identification of isolates revealed in tuna Bacillus lichniforms, Bacillus. mycoides, Bacillus migatarium and Bacillus sterothermophilus in salmon. Bacillus miquerium, Bacillus marins and Bacillus migatarium in sardine Bacillus mycoides, Bacillus 
marins and Bacillus pumilus, marines, mycoides, muquaruim and Bacillus lichniforms in variable incidences among heat treated and non heat treated samples. The total volatile nitrogen base were estimated as indicator for the quality of the tissue protein. The mean values were $39.82+2.54,46.02 \pm 1.77,65.26 \pm 4.63$ and $33.24 \pm 1 . \pm$ in tuna, salmon, sardine and anchovies respectively. Public health hazards and recommended measures to improve the quality and the recommended measures for improving canned fish products were discussed.

Key words: Canned fish, tuna, sardine, salmon, anchovies

\section{INTRODUCTION}

Fish canning industry become well established in Egypt as widely distributed under different market names. The used fish must be first quality frozen, fresh or chilled (Badr, 1982; Akande et al., 1990 and Fava, 1996). Sea foods are low acid foods and have slow rate of heat penetration so are difficult to heat processed. Besides, products such as fish packed in oil must undergo a more severe thermal process than the same food products with different formulation in order to account for the protective effect of oil (Ababouch et al., 1986 and NFPA, 1982).

National academy of science (1985) stated that fish, mollusks and crustaceans acquired pathogenic micro-organisms or toxins from the natural aquatic environment from sewage contaminated harvesting areas and from contamination by workers, utensils and equipment during harvesting, processing and preparation. In addition, Bryan (1988) claimed that, the causes of bacterial foodborne illness transmitted by fish could be attributed to fishing from polluted waters, improper practices of strict sanitation procedures in fishing vesicles, processing plants and storage facilities as well as diseased food handlers

Schwab et al. (1982) found that the aerobic plate count, E coli and Staph. aureus counts were the useful indicators to evaluate faulty processing and /or handling practice.

Bacillus species are ubiquitous in nature, some species are of importance in spoilage of heat treated foods. Five species have been recognized as causative organisms of food poisoning including Bacillus cereus, Bacillus brevis, Bacillus subtilis, Bacillus lichniforms and Bacillus sphericus. Other members of Bacillus spp. may also be associated with food poisoning, diarrhea and emetic types are predominant symptoms (Cilbert et al., 1981; Robert et al., 1996 and Faille et al., 2002) 
Total volatile basic nitrogen (TVB-N) was served only as an indicator of spoilage and did not correlate with storage period (Barile et al., 1985). On the other hand, Srikar et al. (1993) found that TVB-N increased throughout the period of storage, indicating deterioration in the quality of the tissue protein. Also they observed that the lower TVB-N content in products stored at $2.5^{\circ} \mathrm{C}$ may be attributed to the slow rate of hydrolyses. The aim of this study was to investigate and evaluate the bacteriological quality of some canned fish namely tuna, salmon, sardine and anchovies through the aerobic bacterial count, detection and isolation of coliforms, staphylococci and Bacillus spp with studying the public health importance as well as the recommended measures for improving the quality of canned fish.

\section{MATERIALS and METHODS}

105 random samples of canned fishes included 30 tuna, 25 of each salmon, sardine and anchovies were collected from different localities, retail shops and supermarkets in Al-Bohaira province. Samples were dispatched directly to the laboratory with minimum of delay where they prepared and examined chemically and bacteriologically

Preparation of samples for bacteriological examination were done according to A.P.H.A. (1985)

Bacteriological examination:

The prepared samples were subjected to the following examinations.

1- Aerobic plate count (APC) according to APHA (1992)

2- Coliform count using Most Probable Number (MPN) according to A.O.A.C.(1975)

3-Staphylococcus aureus count was carried according to Baird Parker (1962)

4-Enumeration of aerobic spore former according to APHA (1985)

5-Enumeration of aerobic spore former of heat treated samples according to APHA (1985)

6- Identification of isolates was done according to Willis (1977); Macfadian (1980) and Kreg and Holt (1984).

Chemical examination:

Total volatile basic nitrogen (TVB-N) was carried according to FAO (1992) 
Table 1: Statistical analytical results of aerobic plate, coliforms, staphylococci and Bacillus spp. (c.f.u. /gm) of the examined canned fish.

\begin{tabular}{|c|c|c|c|c|c|c|}
\hline \multirow{2}{*}{ Product } & \multirow{2}{*}{$\begin{array}{l}\text { Counted } \\
\text { group }\end{array}$} & \multicolumn{2}{|c|}{ Positive } & \multirow{2}{*}{ Minimum } & \multirow{2}{*}{ Maximum } & \multirow{2}{*}{ Mean + s E } \\
\hline & & $\mathrm{N}$ & $\%$ & & & \\
\hline \multirow{5}{*}{ Tuna } & A PC & 16 & 53.3 & $2 \times 10$ & $1 \times 10^{3}$ & $2.16 \times 10^{2} \pm 7.2 \times 10$ \\
\hline & Coliform & 3 & 10 & $1.2 \times 10^{2}$ & $2.2 \times 10^{2}$ & $1.57 \times 10^{2} \pm 3.2 \times 10$ \\
\hline & Staph & 11 & 36.6 & $2 \times 10$ & $6.8 \times 10^{2}$ & $1.33 \times 10^{2} \pm 5.9 \times 10$ \\
\hline & B.c. unH & 6 & 20 & $1 \times 10$ & $3.7 \times 10^{2}$ & $1.4 \times 10^{2} \pm 6.4 \times 10$ \\
\hline & B.c $\mathrm{H}$ & 7 & 23.3 & $2 \times 10$ & $2 \times 10^{2}$ & $7.29 \times 10 \pm 2.28 \times 10$ \\
\hline \multirow{5}{*}{ Salmon } & APC & 15 & 60 & $1.6 \times 10$ & $2.50 \times 10^{3}$ & $4.6 \times 10^{2} \pm 1.62 \times 10^{2}$ \\
\hline & Coliform & 3 & 12 & $2.3 \times 10$ & $3.7 \times 10^{2}$ & $3.2 \times 10^{2} \pm 4.5 \times 10$ \\
\hline & Staph. & 11 & 44 & $4 \times 10$ & $5 . .6 \times 10^{2}$ & $1.83 \times 10^{2} \pm 7.5 \times 10$ \\
\hline & B.c.unH & 6 & 24 & $2 \times 10$ & $2.2 \times 10^{2}$ & $8 \times 10 \pm 3.3 \times 10$ \\
\hline & B.c. $\mathrm{H}$ & 6 & 24 & $3 \times 10$ & $3.5 \times 10^{2}$ & $1.43 \times 10^{2} \pm 5 \times 10$ \\
\hline \multirow{5}{*}{ Sardine } & APC & 13 & 52 & $3 \times 10$ & $7.2 \times 10^{2}$ & $2.62 \times 10^{2}+5.9 \times 10$ \\
\hline & Coliform & 1 & 4 & $4 \times 10$ & $4 \times 10$ & $4 \times 10$ \\
\hline & Staph & 7 & 28 & $3 \times 10$ & $5.8 \times 10^{2}$ & $1.79 \times 10^{2} \pm 7.2 \times 10$ \\
\hline & B.c. unH & 5 & 20 & $2 \times 10$ & $2.5 \times 10^{2}$ & $9.2 \times 10 \pm 4 \times 10$ \\
\hline & B.c $\mathrm{H}$ & 5 & 20 & $4 \times 10$ & $2.1 \times 10^{2}$ & $9.2 \times 10 \pm 3.3 \pm 10$ \\
\hline \multirow{5}{*}{ Anchovies } & APC & 9 & 36 & $4 \times 10$ & $5.6 \times 10^{2}$ & $1.63 \times 10^{2} \pm 5.3 \times 10$ \\
\hline & Coliform & 3 & 12 & $6 \times 10$ & $1.1 \times 10^{2}$ & $8.3 \times 10 \pm 1.5 \times 10$ \\
\hline & Staph. & 5 & 20 & $2 \times 10$ & $1.2 \times 10^{2}$ & $8 \times 10 \pm 1.64 \times 10$ \\
\hline & B.c. unH & 5 & 20 & $3 \times 10$ & $1.2 \times 10^{2}$ & $5.4 \times 10 \pm 1.7 \times 10$ \\
\hline & B.c. H & 7 & 28 & $3 \times 10$ & $1 \times 102$ & $5.57 \times 10 \pm 0 . .99 \times 10$ \\
\hline
\end{tabular}

B.C.un $\mathrm{H} \quad$ : Bacillus cereus of unheated sample

$\mathrm{BCH} \quad$ : Bacillus cereus of heated samples

Table 2: Means and standard error for aerobic plate count, coliforms, staphylococci and Bacillus spp. of the examined fish.

\begin{tabular}{|c|c|c|c|c|c|}
\hline & APC & Coliforme & Staph. & B.C un heat & B.C Heat \\
\hline Tuna & $2.16 \times 102 \pm 7.2 \times 10^{\mathrm{A}}$ & $1.53 \times 10^{2} \pm 3.2 \times 10^{\mathrm{B}}$ & $1.33 \times 10^{2} \pm 5.9 \times 10^{\mathrm{A}}$ & $1.4 \times 1026.4 \times 10^{\mathrm{A}}$ & $7.29 \times 10 \pm 2.28 \times 10^{\mathrm{A}}$ \\
\hline Salmon & $4.6 \times 10^{2} \pm 1.62 \times 12^{\mathrm{A}}$ & $3.2 \times 10^{2} \pm 4.5 \times 10^{\mathrm{A}}$ & $1.83 \times 10^{2} \pm 7.5 \times 10^{\mathrm{A}}$ & $8 \times 10 \pm 3.3 \times 10^{\mathrm{A}}$ & $1.43 \times 10 \pm 5 \times 10^{\mathrm{A}}$ \\
\hline Sardine & $2.6 \times 10^{2} \pm 5.9 \times 10^{\mathrm{A}}$ & $4 \times 10^{\mathrm{B}}$ & $1.79 \times 10^{2} \pm 7.2 \times 10^{\mathrm{A}}$ & $9.2 \times 10 \pm 4 \times 10^{\mathrm{A}}$ & $9.2 \times 10 \pm 3.3 \times 10^{\mathrm{A}}$ \\
\hline Anchovies & $1.63 \times 10^{2} \pm 5.3 \times 10^{\mathrm{A}}$ & $8.3 \times 10 \pm 1.5 \times 10^{\mathrm{B}}$ & $8 \times 10 \pm 1.64 \times 10^{\mathrm{A}}$ & $5.4 \times 10 \pm 1.7 \times 10^{\mathrm{A}}$ & $5.57 \times 10 \pm 0.99 \times 10^{\mathrm{A}}$ \\
\hline
\end{tabular}

B.C un $\mathrm{H} \quad$ : Bacillus cereus unheated count.

B.C H : Bacillus cereus heated count.

* Counts : Calculated as Mean + Standard Error

* Means $\quad:$ with the same letters $(\mathrm{A}, \mathrm{B}$ are not significantly different $(\mathrm{P}<0.01)$ 
Table 3: Incidence of the identified Gram-ve bacilli isolates

\begin{tabular}{|c|c|c|c|c|c|c|c|c|c|}
\hline \multirow{2}{*}{ product } & \multirow[t]{2}{*}{ Total } & \multicolumn{2}{|c|}{ Positive } & \multicolumn{2}{|c|}{$\begin{array}{c}\text { Kleb. Pneum. } \\
\text { ozaenae }\end{array}$} & \multicolumn{2}{|c|}{$\begin{array}{l}\text { Enterob. } \\
\text { aerogrnes. }\end{array}$} & \multicolumn{2}{|c|}{$\begin{array}{l}\text { Enterob. } \\
\text { intermed. }\end{array}$} \\
\hline & & $\mathrm{N}$ & $\%$ & $\mathrm{~N}$ & $\%$ & $\mathrm{~N}$ & $\%$ & & $\%$ \\
\hline Tuna & 30 & 3 & 10 & 2 & 6.6 & 1 & 3.3 & - & - \\
\hline Salmon & 25 & 3 & 12 & 1 & 4 & 2 & 8 & - & - \\
\hline Sardine & 25 & 1 & 4 & - & - & 1 & 4 & - & - \\
\hline Anchovies & 25 & 3 & 12 & 1 & 4 & 1 & 4 & 1 & 4 \\
\hline Total & 105 & 10 & 9.05 & 4 & 3.8 & 5 & 4.8 & 1 & 0.9 \\
\hline
\end{tabular}

Table 4: Incidence of the identified staphylococci isolates.

\begin{tabular}{|c|c|c|c|c|c|c|c|c|c|}
\hline \multirow{3}{*}{ product } & \multirow{3}{*}{ No } & \multirow{2}{*}{\multicolumn{2}{|c|}{ Positive }} & \multicolumn{6}{|c|}{ Distribution } \\
\hline & & & & \multicolumn{2}{|c|}{ Staph aureus } & \multicolumn{2}{|c|}{ Stph epidermidis } & \multicolumn{2}{|c|}{ Staph saproph. } \\
\hline & & $\mathrm{N}$ & $\%$ & $N$ & $\%$ & $N$ & $\%$ & $N$ & $\%$ \\
\hline Tuna & 30 & 11 & 36.6 & 8 & 26.6 & 3 & $10 \%$ & - & \\
\hline Salmon & 25 & 12 & 48 & 9 & 36 & 2 & $8 \%$ & 1 & 4 \\
\hline Sardine & 25 & 7 & 24 & 3 & 12 & 3 & 10 & 1 & 4 \\
\hline An & 25 & 5 & 20 & 3 & 12 & 2 & 8 & & \\
\hline Total & 105 & 35 & & 23 & & 10 & & 2 & \\
\hline
\end{tabular}

Table 5: Incidence of identified Bacillus spp. isolated from the examined tuna, salmon, sardine and anchovies. 
Table 6: The statistical analy tical results of total volatile basic nitrogen (T.V. B- N) / 100g of the examined canned fish.

\begin{tabular}{|l|c|c|l|l|}
\hline \multicolumn{1}{|c|}{ Product } & N & \multicolumn{1}{c|}{ Min } & \multicolumn{1}{c|}{ Max } & \multicolumn{1}{c|}{ Mean \pm SE } \\
\hline Tuna & 30 & 16.13 & 63.12 & $39.82 \pm 2.54^{\mathrm{A}}$ \\
\hline Salmon & 25 & 31.22 & 65.19 & $46.02 \pm 1.77^{\mathrm{B}}$ \\
\hline Sardine & 25 & 32.13 & 126.19 & $65.26 \pm 4.63^{\mathrm{CB}}$ \\
\hline Anchuvies & 25 & 16.13 & 52.18 & $33.24 \pm 1.910^{\mathrm{C}}$ \\
\hline
\end{tabular}

Measn in the same letter do not differ significantly at $\mathrm{p}=0001$

\section{DISCUSSION}

The results in Tables $(1,2)$ denoted the bacterial counts in different canned fish products under investigations. The incidence of aerobic plate count was. 53. 3, 60. 52 and $36 \%$ for tuna, salmon, sardine and anchovies respectively with means of $2.16 \times 10^{2} \pm 7.2 \times 10,4.6 \times$ $10^{2} \pm 1.62 \times 10^{2}, 2.62 \times 10^{2} \pm 5.9 \times 10$ and $1.63 \times 10^{2} \pm 5.3 \times 10$ respectively. These results are nearly similar to that recorded by Davidson et al. (1981) who reported that $63 \%$ of cans conductive to microbial survival. Higher results were recorded by Ababouch et al. (1986) who claimed that canned fishes packed in oil more are susceptible for holding bacterial contamination due to the fat protection effect which minimizes the thermal effects on preprocessing bacterial loads. Lower incidence was recorded by Paterno and Gopez (1970) who claimed $21.53 \%$ of the examined locally canned food after incubation at $55^{\circ} \mathrm{C}$ contained viable organisms. Foster et al. (1977) recorded higher count for fish fillets, flounder fillets and salmon when ranged from $3.5 \mathrm{x}$ $10^{3}$ to $9.3 \times 10^{4} / \mathrm{gm}$. The lower count in our study could be attributed to the fat and oil protection effects through thermal processing of canned fishes as claimed by NFPA (1982) and Ababouch, et al. (1986). Our results were in accordance with Akande, et al. (1990) who claimed that total viable counts of canned tuna were generally low as ranged from 1.5 $\mathrm{X} 10^{2}$ to $3.5 \times 10^{2}$.

Table (2) denoted that there were no significance variation between the different studied products that could be turned to the lower count of aerobic plate count

Coliform as recorded in Tables (1\&2) for tuna, salmon, sardine and anchovies could be detected in 10, 12, 4 and $12 \%$ respectively. These results abroached to the results of Silverman et al., (1964) on frozen fillets as $19 \%$ of samples were positive. The mean values of coliforms were $1.57 \times 10^{2} \pm 3.2 \times 10,3.2 \times 10^{2} \pm 4.5 \times 10,4 \times 10$ and $8.3 \times$ 
$10 \pm 1.5 \times 10$ in tuna, salmon, sardine and anchovies respectively. Salmon yield significant variation that could be turned to the spices and additives. The presence of coliforms is an index of hygienic quality of fish and shellfish originated from environmental sources and low sanitary precautions during production. and processing (Freeman, 1960; Silvermen, et al. 1964; El-Morshedy et al., 1981 and A.O.A.C., 1975). Table (3) denotes the identified coliform isolates from different examined canned fishes. Enterobacter species including Enterobacter aerogens $(4.8 \%)$ and Enterobacter intermedium (1\%) are the predominant followed by Klebsiella pneumoniae sub ozanae (3.8\%). The summated coliforms in canned fish products were $9.5 \%$. These results are in accordance with Mousa (1986) who could isolate Enterobacter spp, Klebsiella spp in addition Proteus spp and Citrobacter as coliform contaminant of fishes. Our results agreed also with Nambiar (1980) who concluded that coliform exceed $4.5 \%$. Pseudomonas aeruginosa were accidentally isolated only 3 isolates were detected in Tuna (2) and one in salmon. The presence of Pseudomonas occur in proceeded beyond the $3^{\text {rd }}$ day of storage.

Table (1) denoted the frequency of staphylococci isolated from tuna, salmon, sardine and anchovies which were 36.6, 44, 28 and $20 \%$ respectively with mean values of $1.33 \times 10^{2}- \pm 5.9 \times 10,1.83 \times 10^{2} \pm 7.5$ x $10,1.79 \times 10^{2} \pm 7.2 \times 10$ and $8 \times 10 \pm 1.6 \times 10$. Table (2) showed no significance variation between the different products. The identification of the gained isolates revealed 26.6, 36, 12 and12 \% Staphylococus aureus in each of tuna. salmon, sardine and anchovies respectively. These results agreed with Lawson (1970) who recorded that Staphylococcus aureus was rarely recovered from freshly caught fish, but after handling and processing reached from $10-30 \%$. Moreover, presence of Staphylococcus aureus is useful indicator to evaluate faulty processing and / or handling practice.

Concerning aerobic sporeformers they were present in 26.6, 24, 20 and $28 \%$ with means of $1.4 \times 10^{2} \pm 6.4 \times 10,8 \times 10 \pm 3.3 \times 10,9.2 \times$ $10 \pm 4 \times 10$ and $5.4 \times 10 \pm 1.7 \times 10$ in unheated samples, $7.29 \times 10 \pm 2.28$ $\mathrm{x} 10,1.43 \times 10^{2} \pm 5 \times 10,9.2 \times 10 \pm 3.3$ and $5.57 \times 10 \pm 0.99 \times 10$ in heat treated tuna, salmon, sardine and anchovies respectively. Statistically, there were no significance variations between products at $\mathrm{p}>0.01$. These results agreed with Ababoush et al. (1986) who found $28 \%$ of canned fishes contained typical under processing spoilage organisms pure culture of aerobic and anaerobic spore former bacilli. Lower results were recorded by Pavlov (1989) who found $16 \%$ in canned meat. The 
incidence in anchovies could be attributed to the use of solar salts which may be rich with Bacillus species as recorded by Shewan, (1971). Higher incidence was recorded by Davidson et al. (1981) who claimed that, $63 \%$ of high protein food products such as fish are very conductive to microbial survival .Also they found pure cultures of aerobic and anaerobic spore forming bacilli. Lowest count of aerobic spore former was detected by khalaf and Marth (1984). It was 2 c .f. u / gm for cans of sardine and tuna in U.S supermarkets. The sources of contamination as recorded by National Academy of Science (1985) in fishes could be attributed to natural aquatic environment from sewage, contaminated harvesting areas and from contamination by workers, utensils and equipment during harvesting, processing distribution and food preparation. Table (5) declared the identified aerobic spore forming bacilli in all the examined canned fishes in tuna 23 were recovered. $47.7 \%$ were isolated from un-heat treated and $52.3 \%$ from heat treated samples. These isolates were Bacillus marins 4 (17.2\%), 1(4.3\%) Bacillus. circulans. 2 (8.6 \%) Bacillus Pumilus 4 (17.2) \% Bacillus lichnforms, $521.0 \%$ Bacillus. mycoides 3 Bacillus migatariam 2 and Bacillus. mequarium out of 25 sample from heated and unheated samples. Sardine yielded 10 isolates 2 Bacillus marins 4 Bacillus mycoides. 4 Bacillus migatarium. Finally anchovies yielded 19 isolates (6 Bacillus marins, 2 Bacillus pumilis, 5 Bacillus lichniformes, 3 Bacillus mycoides and 3 Bacillus maquarium). These results agreed with Herson and Hulland (1980). In addition Rodel and lucle (1990) reported that storage with inadequate refrigeration of commercially pasteurized sealed cans caused spoilage of product where Bacillus lichniforms and Bacillus subtilis frequently isolated. Many of the gained isolates were recorded as food poisoning organisms as recorded by Hadlock (1983).

Table (6) shows the statistical analytical results of total volatile basic nitrogen (T.V.B.- N / $100 \mathrm{gm}$ ) of the examined tuna, salmon sardine and anchovies the minimal values were $16.13,31.22,32.13,16.13$ respectively the maximal reached $63.12,65.19,126.19$ and $52.18 / 100 \mathrm{gm}$ respectively. The component of T.V. B- $\mathrm{N}$ found in small quantities in fresh fish flesh as increased with time of storage as correlation between increase spoilage proceeds and increase fishy odor. The mean values of TVB-N as in Table (6) were $39.82 \pm 2.54,46.02 \pm 1077.65 .26 \pm 4.63$ and $33.24 \pm 1.91$ in tuna, salmon, sardine and anchovies respectively. These results agreed with El-Wakeil et al. (1975) who found an increase in both T V B N from 17.2 in fresh fish to $18.4,44,75,120,13176.8$ and $115 \mathrm{mg} /$ $100 \mathrm{~g}$ in salted fishes stored for $0,30,60,90$ and 120 days respectively .In 
additions El-Sharnouby et al., (1989) found an increase in TV B- $\mathrm{N}$ from 28.44 up to $81067 \mathrm{mg} \%$ in finished product of salt cured gray mullet while in fresh fish increased from $20.75 \mathrm{mg} \%$ to $121.2 \mathrm{mg} \%$ in salted cured conman crap. The statistical analysis revealed significant decrease in anchovies than other products. These results are in accordance with Hernandez - Herrero (1997) who supposed that, a part of T.V.B. N content diffused into the brine with other nitrogen fractions. Our gained results are within limit of acceptance as Connell (1990) who reported that the content of TVBN used as indicator for estimating the freshness of lean fish and suggested that $200 \mathrm{mg} / 100 \mathrm{gm}$ are the maximal limit for marine fish.

\section{REFERENCES}

Ababouch, L.; Chougur, l. and Busta, F.F. (1986): Causes of spoilage of thermally processed fish in Morocco, FAO fisheries Report, No. 329.

Akande, G.R.; Emokpae, A.O.; Towuru, E.T.; Ogbonna, C. and Ajayi, A. (1990): Proximate composition, microbiological and sensory evaluation of canned skipjack tuna stored at ambient and accelerated temperatures. FAO- Fisheries - Report, No. 4000.

A.O.A.C. (1975): Association Official Analytical Chemist Official Methods of Analysis $12^{\text {th }}$ ed. P.O. Box 540 Benjamin Franklin Station Washington

(A.P.H.A) American Public Health Association (1985): Standard Methods for the Examination of Dairy Products $13^{\text {th }}$ ed. Hausler, W. J., Washington, D.C.

(A.P.H.A) American Public Health Association (1992): Compendium Methods for Microbiological Examination of Food $3^{\text {rd }}$ ed brothers Ann Arb

Badr, F.H. (1982): Chemical and microbiological studies on canned fish. Thesis for M. V. Sc in Food Science. Fac. of Agric., Zagazig Univ.

Baird-Parker, A.C. (1962): An improved diagnostic medium for isolating coagulase positive staphylococci J. Appl. Bact., 25, 12-19.

Barile, L.E.; Estrada, M.H.; Mila, A.D.; Reilly, A. and Villaden, A. (1985b): Spoilage patterns of mackerel (Rasterelliger faughni Matsui). 2. Mesophilic versus psychotropic fish spoilage of tropical fish. ASEAN. Food J., $1: 121-126$. 
Bryan, F.L.; Michanie, S.C.; Alvares, P. and paniaaga, A. (1988): Critical control points of street - vended food in the Dominican Republic J. Food Prod., 51 (50): 373 - 383.

Cilbert, R.J.; Turnbull, P.C.B.; parry, J.M. and Kramer, J.M. (1981): Bacillus cereus and other Bacillus species: Their part in food poisoning and other clinical infections. In Brekeley R.C.W. and good fellow (Eds), the Aerobic Endospore Forming Bacteria Academic press, London and New York, Pp. 131-150 and 297 $-314$.

Connell, J.J. (1990): Control of Fish Quality., $3^{\text {rd }}$ ed.. Blackwell Scientific publications, Oxford, pp. $85-88,97-103$.

Davidson, P.M.; Pflug, I.J. and Smith, G.M. (1981): Microbiological analysis of food product in swelled cans of low acid food collected from supermarkets. J. Food Protect. 44 (9) 686 - 91.

El-Morshdy, A.; Zeidan, M.A. and Sedik, M.F.S. (1981): Studies on physical, chemical and bacteriological. Status of salted fishes in Sharkia province. Cited after Mousa (1986)

El-Sharnouby, M.R.; Saddik, M.F.; El-Hossany, M.M. and Abd Elkadir, M. (1989): Staphylococcus aureus associated with meat and meat products. Bull. Nutr. Inst., Arab Rep. Egypt., 9 (1): 27.

El-Wakeil, F.A; khairy, M.; morsi, S. and Abo - Raya, S.H. (1975): Chemical and biological evaluation of fresh and preserved lake Nasser's fish. II. Salt - dried Keshr -Bayad "Latus niloticus". Egypt. J. Food Sci ., 3 (1- 2) : 65.

Faille, C.; Member, J.M.; kutaczka, M. and Gavini, (2002): Cabability Bacillus cereus spores to grow under unfavorable conditions (presence of niacin, low temperature, acidic $\mathrm{pH}$, presence of Na. cl) following Heat treatment during sporulation J. Food Prot. 65: 1930 - 1936.

Fava, A. (1996): process for processing tuna - fish prior to its canning. European patent Application Epo 704 - 159 A2.

Food and Agricultur Organisation (FAO) (1992): Manual of quality control Part 4 Food and agriculture organization.

Foster, J.F.; Fowler, J.L. and Dacey, J. (1977): A microbial survey of various fresh and frozen seafood products. J. Food Protect. 40 (5) $300-303$.

Freeman, W.H. (1960): The science of meat and products. American Meat Institute Foundation. Reinhold publishing corporation, New York. 
Hadlok, R.M. (1983): Die Bedeutung der Gattunge Bacillus in der labens mittell hygiene, Schriftenreihe Schweiz. Ges Lebnsmittelhyg. 13, 68-106.

Hernandez - Herrero, M.M. (1997): Influencia de la calidad higienicadel boqueron (Engraulis encrasicholus var. Mediterraneas) durante la maduracion dela anchoa. Tesis Doctoral. Universitat Autonoma de Barcelona, Barcelona, Spain.

Herson, A.C. and Hulland, E.D. (1980): Canned food thermal processing and microbiology 7th ed., J. and A. Churchill Limited, London.

Khalaf, H.H.; Marth, E.H. (1984): Aerobic and anaerobic bacteria in commercially canned baby foods and other products. Annals of Agric. Sc .Moshtohor., 21 (3) 753 -768.

Krig, N.R. and Holt, J.G. (1984): Bergey's Manual of Systemic Bacteriology. Vol. 2, Williams and Wilkins, Baltimore, London.

Lawson, J.B. (1970): Some aspects of fish inspection and public health. Vet. Rec., 87: 528. 534

Macfadian, J.F. (1980): Biochemical tests for identification of medical bacteria. The Williams and wilkins company, Baltimore, U. S. A.

Michigan University (1988): M.S.T.A.T.C Software program for the design management and analysis of agronomic research experiment Michigan USA.

Mousa, M. (1986): Microbiology of some fish and shell fish in local markets and its relation to public health. ph. D. Thesis, Food hyaen Dept.., Alex. Univ. Fac. Vet. Med.

Nambiar, V.N. (1980): Bcteriology of spoilage of canned prawns Techol., 17 (1) 35-39

National Academy of Science (1985): An evaluation of the role of microbiological criteria for foods and food ingredients. National Academy Press, Washington, D.C.

(NFPA) National Food processors Association (1982): Thermal processes for low acid foods in metal container. Bull. Nat. Food process. Assoc. Res. Lab., (261) 12 th Ed.

Paterno, V.A. and Gopez, M.D. (1970): Microbiology of Locally canned foods. Philippine Journal of Nutrition, 197, 23 (1) 21- 31.

Pavlov, G. (1989): Thermophilic microorganisms in sterilized canned foods. Veterinaries. Sb. Oirka, 87 ( 9 ) $51-53$. 
Robert, T.A.; Baisd - parker, A.C. and Tompk in. C.B. ed (1996): Microorganisms in foods. Microbiological specification of food pathogens Blackie Academic and professional London

Rodel, W. and Lucle, F.K. (1990): Effect of redox potential on Bacillus subtilis and Bacillus Licheniformis in broth in pasteurized sausage mixtures. International Journal of Food Microbiology 10: 3-4, $291-302$.

Schwab, A.H.; Swartzentruber, A.; wentez, B.A. and Read, Jr, R.B. (1982): Microbiological quality of infant milk foods. Assuit Vet. Med. J. 12 (23): 137-142

Shewan, J.M. (1971): The microbiology of fish and fishery products. J. Appl. Bact., 34: 299 - 315.

Silverman, G.J.; Norman, S. and John, T.R. (1964): Gertain microbial indices of frozen uncooked fish. J. food Sci., 29 (1): 331- 336.

Srikar, L.N.; khuntia, B.K.; Reddy, G.V.S. and Srinivasa, B.R. (1993): Influence of storage temperature on the quality of salted mackerel. J. Sci. Food Agric., 63 (3): 319.

Willis, A.T. (1977): Anaerobic bacteriology, clinical and laboratory, clinical and laboratory practice. $3^{\text {rd }}$ ed., Bultimore Butter Worths, London. 